\title{
Wide Spread Exploitations of Bioenergy: Are the Ways towards Sustainable Energy?
}

\author{
Md. Mizanur Rahman, Jukka V. Paatero, and Risto Lahdelma
}

\begin{abstract}
The recoverable proven reserves of fossil fuel sources are projected to be exhausted by the end of this century. In response to the exhaustion of fossil resources, there is a serious need to find alternative fuel sources. Bioenergy is one of the potential candidates to counteract the fossil-fuel depletion challenge. Despite bioenergy sources appear to be renewable and net-zero GHG emitting, bioenergy undergoes competition with food, feed and other crucial applications. Since earth's eco system has a limited capacity of land and water resources, overuse of these resources in bioenergy production could cause adverse social and environmental impacts. This paper summarizes the key sustainability issues involve in bioenergy chain, and examine the potential role of bioenergy in dealing with these sustainability issues. We found that bioenergy can be a sustainable source of energy provided that it has maintained irrationality is using of natural resources and several limits. In contrary, bioenergy would provoke further social and environmental problems if the sustainability issues are not given proper consideration.
\end{abstract}

Index Terms-Bioenergy, food, land, water.

\section{INTRODUCTION}

Conventional fossil fuel resources such as coal, oil and natural gas account for more than $80 \%$ of the global primary energy supply. If the current trend of consumption and energy supply pattern continue, the fossil fuel reserve will be completely exhausted by the end of this century. Fossil fuels are also making environmental degradation and causing climate change. Depletion of fossil fuel reserves and the impact of environmental pollution have led to the search for suitable alternatives for energy [1]. Biomass is one of the abundant renewable energy resources to switch fossil fuels to renewable and to mitigate emissions [2]. Since biomass is formed by fixing $\mathrm{CO}_{2}$ in the atmosphere during the process of plant photosynthesis, it is carbon neutral in its lifecycle. Considering the renewability and carbon neutral nature, bioenergy has received a great attention. Despite the benefits of bioenergy over other energy types, bioenergy is also perceived as a less prospective and low status fuel. Wider acceptance of biomass as an environment friendly resource is still restrained by many misconceptions [3]. Sustainability issues of bioenergy have been studied by many researchers [3]-[8]. Nevertheless, there is a lack of understanding whether bioenergy is fully environment friendly or its sustainability is

Manuscript received September 5, 2014; revised July 12, 2015.

Md. Mizanur Rahman was with Aalto University, School of Engineering, FI-00076 Aalto, Espoo, Finland. He is now with Universiti Teknologi Malaysia (UTM), Johor Bahru, Malaysia (e-mail: mizanur@fkm.utm.my).

Jukka V. Paatero and Risto Lahdelma are with Aalto University, Schoo of Engineering, FI-00076 Aalto, Espoo, Finland (e-mail: jukka.paatero@aalto.fi, risto.lahdelma@aalto.fi). subject to constraints and limits. This study highlights the key sustainability issues involved in the bioenergy development chain and discuss to what extents bioenergy deals with these issues.

\section{BIOMASS AND BIOENERGY}

All forms of organic material originated from living species i.e. forests, plants, crops, algae, forestry, municipal waste, garbage, manure etc. are biomass. Sun's energy when intercepted by plants and converted by the process of photosynthesis into chemical energy is fixed or stored in the form of terrestrial and aquatic vegetation. When biomass is converted into energy it is called bioenergy. Bioenergy is an inclusive term for all forms of biomass and biofuels. Modern bioenergy are produced from biomass through industrial process, and used in industries, power plants, and transport sectors [9]. The ways to transform biomass to bioenergy are usually consist of thermochemical, thermal, and biochemical conversion processes. There are three forms of bioenergy i.e. biofuels, power, and heat.

\section{SUSTAINABILITY ISSUES IN BIOENERGY}

The major inputs into bioenergy production are land and water resources, which are also very essential for food and feed productions [10]. Though biomass is a renewable energy resource, bioenergy faces a number of sustainability issues. Addressing of these sustainability issues are the prerequisite for the sustainable bioenergy. To conduct the sustainability assessment of bioenergy, several key factors were identified by the researchers [11]. Bioenergy will be sustainable if it has successfully gone through a comprehensive examination under all the sustainability issues in regards to social, economic, and environmental dimensions. In contrary, failure to conform to these sustainability issues would provoke further societal and environmental problems [7]. The key issues, which to be conform by the bioenergy development chain for its sustainability are presented in Table I. Against each issue, we have presented discussion to what extents the bioenergy conforms to meet these issues and what are their threshold limits.

\section{A. Land Availability}

The bioenergy potential depends to a great extent on land availability. Currently, the amount of land devoted to growing biofuels is only 0.025 Gha or $0.19 \%$ of the world's total land area of 13.2 Gha and $0.5-1.7 \%$ of global agricultural land of $1.53 \mathrm{Gha}$. Estimates of the total global bioenergy production potential in 2050 ranged from 33 to 1,135 EJ annually [12]. 
TABLE I: KEY SUSTAINABILITY ISSUES CONNECTED WITH BIOENERGY

\begin{tabular}{|c|c|c|c|}
\hline Social issue & $\begin{array}{l}\text { Environmental } \\
\text { issue }\end{array}$ & $\begin{array}{l}\text { Economic } \\
\text { issue }\end{array}$ & Reference \\
\hline $\begin{array}{l}\text { Land } \\
\text { availability }\end{array}$ & $\begin{array}{l}\text { Life-cycle GHG } \\
\text { emissions }\end{array}$ & $\begin{array}{l}\text { The energy } \\
\text { production } \\
\text { price }\end{array}$ & {$[6],[11]$} \\
\hline $\begin{array}{l}\text { Food, feed and } \\
\text { other } \\
\text { competitions }\end{array}$ & $\begin{array}{l}\text { Depletion of fresh } \\
\text { water resource }\end{array}$ & & {$[8]$} \\
\hline \multirow{3}{*}{$\begin{array}{l}\text { Employment } \\
\text { opportunity }\end{array}$} & Biodiversity & & {$[3]$} \\
\hline & Soil erosion & & [7] \\
\hline & $\begin{array}{l}\text { Nutrient removal } \\
\text { and losses }\end{array}$ & & [7] \\
\hline
\end{tabular}

In individual bases, the minimum arable land required to sustainably support one person is 0.07 ha whereas per capita available arable land in 2050 is projected as 0.17 ha (Fig. 1) [13]. Beyond arable land, 0.25 ha per capita is also available as permanent meadow and pasture land, which could be suitably upgraded to cropland (Fig. 2).

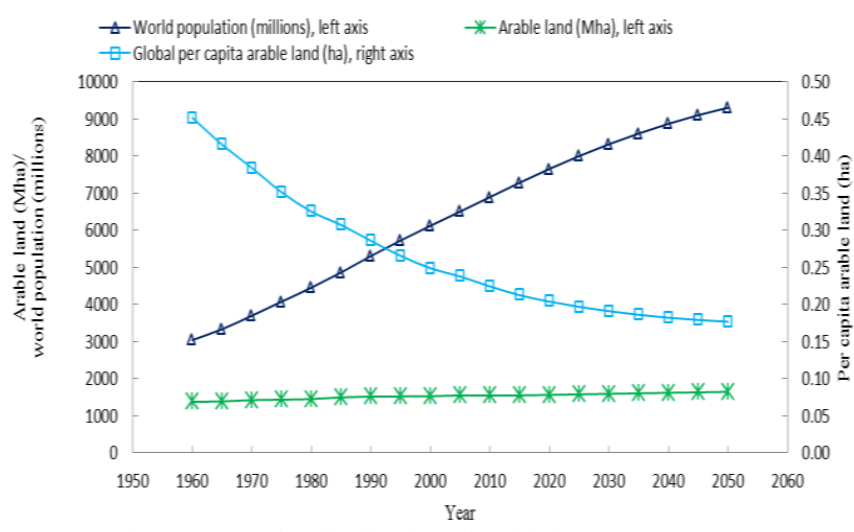

Fig. 1. Per capita distribution of arable land: 1950-2060.

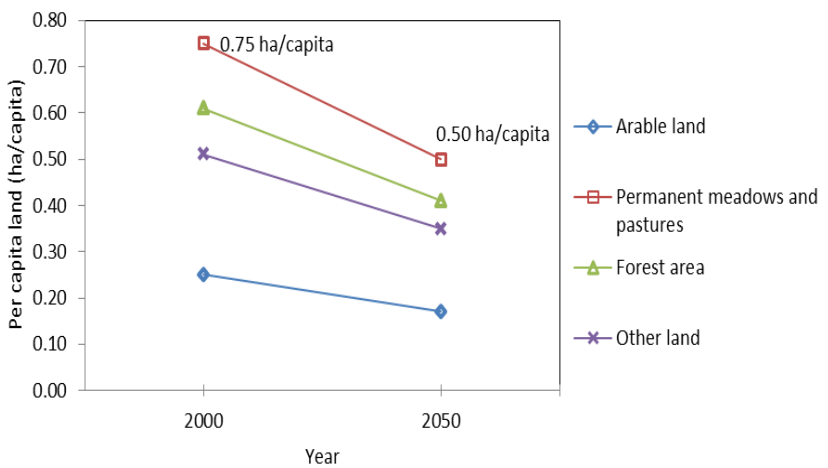

Fig. 2. Per capita distribution of total meadow and pasture land in global scale: $2000-2050$.

\section{B. Food, Feed and Other Competitions}

The bioenergy will be sustainable only when the feedstock biomass come after meeting the needs for other so called "6F"applications namely food, fodder, fertilizer, fiber, feedstock, and further uses. These challenges can be overcome if feedstock are chosen from two ways-biomass that are produced in surplus land and biomass that are surplus after other applications. To estimate the surplus biomass, it is necessary to establish the present utilization pattern of biomass. Then it gives the surplus availability factor $\left(F^{\text {saf }}\right)$ of the biomass. The surplus biomass can be determined as Eq. 1 . Several studies show that energy production from surplus biomass can be sufficient to meet the energy needs [14].
Energy crops from surplus agricultural land have the potential of $988 \mathrm{EJ} /$ year [15].

$$
M^{s}=M^{p} \times F^{s a f}
$$

where, $M^{s}$ is surplus biomass after all ' $6 \mathrm{~F}$ ' applications, $M^{p}$ is total biomass production.

\section{Employment}

Bioenergy offers creation and retention of local jobs in rural economy. For biomass power systems, extra 15 to 20 jobs for each MW are created for fuel processing and delivery. Bioenergy also caused greater occupational hazards associated with the possibilities of increased employment. Agriculture sector are accountable for $25 \%$ more injuries per man-day than all other private industries [16].

\section{Life Cycle GHG Emissions}

The use of bioenergy sources could reduce the GHG (greenhouse gas) emissions. One study says that sustainable use of biomass to bioenergy emits net zero $\mathrm{CO}_{2}$ to the atmosphere [17]. The lifecycle emissions for different renewable and non-renewable sources are summarized in Table II [18]. The table shows that biomass emits very little emissions comparing to non-renewable energy sources.

TABLE II: LIFE CYCLE EMISSIONS FOR DIFFERENT RENEWABLE AND NON-RENEWABLE FUELS [18]

\begin{tabular}{|c|c|c|c|}
\hline Type of sources & Sources & $\begin{array}{l}\text { Configuration and } \\
\text { technology }\end{array}$ & $\begin{array}{l}\text { Emission } \\
\left(\mathrm{gCO}_{2} \mathrm{e} / \mathrm{kWh}\right)\end{array}$ \\
\hline \multirow{7}{*}{$\begin{array}{l}\text { Biomass and } \\
\text { other } \\
\text { renewables }\end{array}$} & Geothermal & $\begin{array}{l}80 \mathrm{MW} \text {, hot dry } \\
\text { rock }\end{array}$ & 38 \\
\hline & Hydroelectric & $\begin{array}{l}300 \mathrm{~kW}-3.1 \mathrm{MW} \text {, } \\
\text { reservoir, } \\
\text { run-off-river }\end{array}$ & $10-13$ \\
\hline & Wind & $\begin{array}{l}1.5 \mathrm{MW} \text {, onshore, } \\
\text { offshore }\end{array}$ & $9-10$ \\
\hline & Biogas & $\begin{array}{l}\text { Anaerobic } \\
\text { digestion }\end{array}$ & 11 \\
\hline & Biomass & $\begin{array}{l}\text { Biomass in various } \\
\text { configuration }\end{array}$ & $14-41$ \\
\hline & Solar thermal & $\begin{array}{l}80 \mathrm{MW} \text {, parabolic } \\
\text { trough }\end{array}$ & 13 \\
\hline & Solar PV & $\begin{array}{l}\text { Polycrystalline } \\
\text { silicone }\end{array}$ & 32 \\
\hline \multirow[t]{3}{*}{ Non-renewables } & Natural gas & $\begin{array}{l}\text { Various combined } \\
\text { cycle turbines }\end{array}$ & 443 \\
\hline & Oil & $\begin{array}{l}\text { Various generator } \\
\text { and turbine types }\end{array}$ & 778 \\
\hline & Coal & $\begin{array}{lr}\text { Various } & \text { generator } \\
\text { types } & \text { with } \\
\text { scrubbing } & \\
\end{array}$ & 960 \\
\hline
\end{tabular}

\section{E. Depletion of Fresh Water Resource}

Bioenergy production chains require large amounts of water resource. For instance, agricultural crop production requires huge water by several orders of magnitude than is needed for domestic and industrial needs. It also contributes significantly to water pollution via the pesticides and fertilizers that are inevitably needed in sustaining any intensive cultivation. In addition, the removal of water for energy production programs may increase soil and water degradation, flooding and removal of nutrients. Perennial energy crops receive low levels of fertilizers or pesticides that can serve as filters if planted along streams [19]. 
Reconciliations of water resources among competing applications are the main tools to overcome this challenge.

\section{F. Biodiversity (Natural Biota, Habitats and Wildlife)}

Conversion of natural ecosystems into energy-crop plantations will change both the habitat and food sources of wildlife and other natural biota. Alteration of forests and wetlands will reduce many preferred habitats and mating areas of some mammals, birds and other biota. The clearance of forestland and its subsequent use for crop production cause significant environmental problems thus the forest land needs to be excluded form energy production [10].

\section{G. Soil Erosion}

Soil erosion is a gradual process of detaching and removing soil particles due to impact of water and wind. Soil erosion negatively affects the crop productivity of the soil with losses of water holding capacity, soil nutrients, soil density and soil organic matters. Eroded soils are deposited in rivers, lakes and reservoirs, and resulting in navigation and other economic losses. During the last 50 years, soil erosion has contributed to the loss of 430 Mha of cropland in the world, which account for one-third of the total arable land. Thus, soil erosion is a crucial factor to the sustainability of bioenergy production and agriculture productivity. Biomass energy production projects can exacerbate soil erosion problems. For instance, the deforestation is performed for fuel wood and several other cultivations, which is a major source of soil erosion. It has been studied that displacing annual crops with perennial biomass crops would reduce run-off, decreasing soil erosion and improving water quality [20].

\section{H. Nutrient Removal and Loses}

Significant nutrient loss will be incurred by the harvesting of crop residues for biomass energy. With the corn yield of $7840 \mathrm{~kg} / \mathrm{ha}$, the nutrients contained in both grain and residues are $224 \mathrm{~kg} \mathrm{~N}, 37 \mathrm{~kg} \mathrm{P}, 140 \mathrm{~kg} \mathrm{~K}$, and $6 \mathrm{~kg} \mathrm{Ca}$; nearly half of the nutrients are on the residues. Thus, nitrogen and other nutrients must be replaced for each subsequent crop. In contrast to high-yield food crops that pull nutrients from the soil, energy crops improve soil quality. Further, the conversion of land from intensive annual crop production to perennial herbaceous species progressively increases the soil's organic matter content [21].

\section{The Energy Production Cost}

Bioenergy production costs vary widely over feedstock, conversion process, scale of production, and regions. A study summarizes bioenergy production costs from different feedstock s and configurations [11]. The production costs range from -7.5 to $16.4 \mathrm{US} \phi / \mathrm{kWh}$, which give an average cost of $6.9 \mathrm{US} \notin / \mathrm{kWh}$. According to this estimate, the energy production from biomass is not cost competitive with other fossil fuel technologies, which produce electricity energy with the range of $4.2-4.8 \mathrm{US} \notin / \mathrm{kWh}$. However, when all the externality costs and direct and indirect subsidies are included in the comparison, the energy production costs for bioenergy become much lower than fossil based energy. The externality costs are the various indirect costs incurred due to the effects of GHG emissions, water pollution, land use, health problems, accidents etc. Sovacool [22] reported the externality costs for different fossil fuels and biomass based electricity (Table III).

TABLE III: EXTERNALITY COSTS FOR FOSSIL, NUCLEAR AND BIOMASS BASED POWER GENERATION

\begin{tabular}{ll}
\hline \hline Power generation fuel & Externality costs (US $\notin / \mathrm{kWh})$ \\
\hline Coal & 19.14 \\
Oil and natural gas & 12.00 \\
Nuclear power & 11.10 \\
Biomass power & 6.70 \\
\hline \hline
\end{tabular}

\section{ExClusive PATHWAY TO AVOID COMPETITION}

Bioenergy systems that do not compete with other inevitable applications and not beyond the threshold limits of bio-capacity can be the exclusive pathways for bioenergy. Bioenergy from forest and agricultural residues, dedicated energy crops on surplus lands, and second generation biofuels are the potential pathways for bioenergy.

\section{A. Forest and Agriculture Residues}

Bioenergy based on surplus forest and agriculture residues require no additional land resources. The surplus residues are obtained after meeting the inevitable environmental and social requirements, thus it will not cause competition with other applications. Bioenergy has a big potential within the present agricultural system through the use of surplus agricultural and forest residues.

\section{B. Biomass Cultivation on Degraded and Marginal Land}

Degraded and marginal land could be rehabilitated by bioenergy plantations which also could combat desertification and other environmental concerns. Sufficient land can be available as agricultural land from grassland and marginal lands.

\section{Second Generation Biofuels}

Second generation biofuels, are seen as a prominent candidate for realizing efficient use of land and bio recourses [21]. Sustainability of many first-generation biofuels, which are produced primarily from food crops such as grains, sugarcane and vegetable oils have been increasingly questioned over concerns such as reported displacement of food-crops. However, second-generation biofuels produced from agricultural or forestry residues do not require cultivation of additional land.

\section{CONCLUSIONS}

Bioenergy has the potential to address fossil fuel depletion and environmental degradation challenges. The sustainable bioenergy supply capacity would be around $900 \mathrm{EJ} / \mathrm{y}$, which is sufficient to provide global energy demands. The major input for bioenergy are land and water resources, thus challenges lay in competition with these natural resources. Bioenergy can also be sources for many issues such as depletion of water resources, soil erosion and loss of biodiversity, however, rational bioenergy production could successfully address these issues. Bioenergy releases almost net zero GHG emissions to the atmosphere on lifecycle basis. Bioenergy has potential to integrate with rural development and could bring other benefit such as employment facility, 
rural development, improve soil quality remove fossil fuel dependence. Conversely, inappropriate bioenergy development could provoke further social and environmental damage. Bioenergy development could address fossil fuel depletion and environmental challenges or equally cause significant damages depending on the paths taken.

\section{ACKNOWLEDGMENT}

The authors are grateful to Aalto University School of Engineering, Finland for providing funding support for this research. The authors also express their gratitude to the anonymous reviewers for providing valuable comments to improve this paper.

\section{REFERENCES}

[1] A. Demirbas, "Biodiesel from oilgae, biofixation of carbon dioxide by microalgae: A solution to pollution problems," Applied Energy, vol. 88, issue 10, pp. 3541-3547, 2011.

[2] M. Ni, D. Y. C. Leung, M. K. H. Leung, and K. Sumathy, "An overview of hydrogen production from biomass," Fuel Processing Technology, vol. 87, issue 5, pp. 461-472, 2006.

[3] D. O. Hall and J. I. Scrase, "Will biomass be the environmentally friendly fuel of the future?" Biomass Bioenergy, vol. 15, pp. 357-367, 1998.

[4] A. Demirbas, "Political, economic and environmental impacts of biofuels: A review," Applied Energy, vol. 86, pp. S108-S117, 2009.

[5] M. F. Demirbas, M. Balat, and H. Balat, "Potential contribution of biomass to the sustainable energy development," Energy Convers. Manag., vol. 50, pp. 1746-1760, 2009.

[6] P. Carneiro and P. Ferreira, "The economic, environmental and strategic value of biomass," Renew. Energy, vol. 44, pp. 17-22, 2012.

[7] E. M. W. Smeets and A. P. C. Faaij, "The impact of sustainability criteria on the costs and potentials of bioenergy production," Biomass and Bioenergy, vol. 34, pp. 319-333, 2010.

[8] B. Phalan, "The social and environmental impacts of biofuels in Asia: An overview," Appl. Energy, vol. 86, pp. S21-S29, 2009.

[9] A. Demirbas, "Biofuels securing the planet's future energy needs," Energy Convers. Manag., vol. 50, pp. 2239-2249, 2009.

[10] M. M. Rahman, S. B. Mostafiz, J. V. Paatero, and R. Lahdelma, "Extension of energy crops on surplus agricultural lands," Renew. Sustain. Energy Rev., vol. 29, pp. 108-119, 2014.

[11] A. Evans, V. Strezov, and T. J. Evans, "Sustainability considerations for electricity generation from biomass," Renew. Sustain. Energy Rev. vol. 14, pp. 1419-1427, 2010.

[12] S. Ladanai and J. Vinterbäck. (2010). Biomass for energy versus food and feed, land use analyses and water supply. [Online]. Available: http://pub.epsilon.slu.se/5562/

[13] G. Fischer, E. Hizsnyik, S. Prieler, and D. Wiberg, "Scarcity and abundance of land resources: Competing uses and the shrinking land resource base," 2010.

[14] R. Moreira, "Global biomass energy potential," Mitigation and Adaptation Strategies for Global Change, vol. 11, issue 2, pp. 313-333, 2006.
[15] J. O. Metzger and A. Hüttermann, "Sustainable global energy supply based on lignocellulosic biomass from afforestation of degraded areas," Naturwissenschaften, vol. 96, pp. 279-288, 2009.

[16] Technology Roadmap Bioenergy for Heat and Power, IEA: Paris, France, 2012.

[17] G. Fischer and L. Schrattenholzer, "Global bioenergy potentials through 2050," Biomass Bioenergy, vol. 20, pp. 151-159, 2001.

[18] B. K. Sovacool, "Valuing the greenhouse gas emissions from nuclear power: A critical survey," Energy Policy, vol. 36, pp. 2950-2963, 2008.

[19] E. G. Brockerhoff, H. Jactel, J. A. Parrotta, C. P. Quine, and J. Sayer, "Plantation forests and biodiversity: Oxymoron or opportunity?" Biodivers. Conserv., vol. 17, pp. 925-951, 2008.

[20] Intelligent Energy Europe. (2009). Energy from field energy crops - A handbook for energy producers. [Online]. Available: http://www.aebiom.org

[21] A. Eisentraut. (2010). Sustainable production of second-generation biofuels: Potential and perspectives in major economies and developing countries. [Online]. Available: http://www.iea.org/publications/

[22] B. K. Sovacool, "Rejecting renewables: The socio-technical impediments to renewable electricity in the United States," Energy Policy, vol. 37, pp. 4500-4513, 2009.

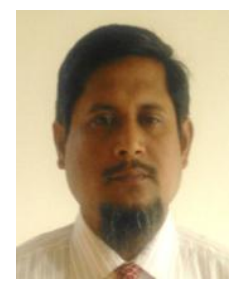

Md. Mizanur Rahman is currently a senior lecturer in the Department of Thermo-Fluids, Faculty of Mechanical Engineering, Universiti Teknologi Malaysia UTM. Before joining the UTM, he has served as a postdoctoral researcher at Aalto University School of Engineering, Finland. He received his Ph.D. degree in energy technology from Aalto University, Finland and M.Sc. degree in sustainable energy engineering from Royal Institute of Technology KTH, Sweden. Dr. Rahman's research interests include energy economics, energy system analysis, rural electrification, sustainable and renewable energy, energy efficiency, and distributed power generation.

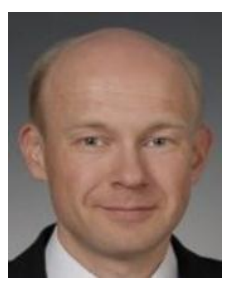

Jukka V. Paatero is a senior university lecturer in the Department of Energy Technology, Aalto University, Finland. He received his Ph.D. and M.Sc. degrees from Helsinki University of Technology HUT, Finland. He has expertise in simulation of various kinds of phenomena and systems as well as development of simulation platforms. Dr. Paatero's research interests include energy economics, system analysis, distributed power generation, energy policy, renewable energy, energy consumption, teaching and group work methods.

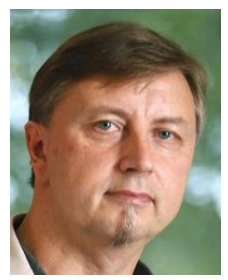

Risto Lahdelma is a professor in the Department of Energy Technology, Aalto University, Finland. He received his $\mathrm{Ph} . \mathrm{D}$. degree in applied mathematics and M.Sc. degree in systems and operations research from Helsinki University of Technoly HUT, Finland. He has expertise in complex system analysis and decision making processes. Professor Lahdelma's research interests include stochastic multicriteria acceptability analysis (SMAA), public environmental decision making, strategic planning, production planning and logistics. 
Clean Energy Technology 
